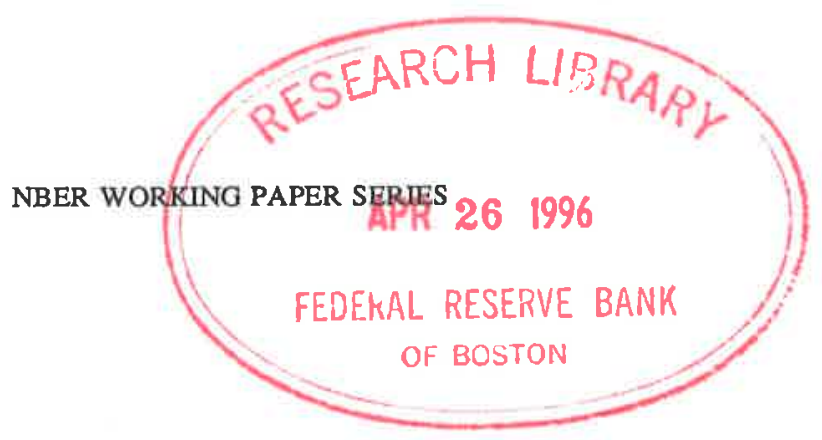

\title{
DO UNIONS MAKE \\ ENTERPRISES INSOLVENT?
}

\author{
Richard B. Freeman \\ Morris M. Kleiner
}

Working Paper No. 4797

\section{NATIONAL BUREAU OF ECONOMIC RESEARCH \\ 1050 Massachusetts Avenue \\ Cambridge, MA 02138 \\ July 1994}

The authors want to thank Tzu-Shian Han, Scott Leitz, Doreen Johnson, and Mohan Ramanujan for their excellent research assistance. We also thank Barry Hirsch for providing us with firm level unionization information. Thanks also to participants at research seminars at Comell University, London School of Economics, NBER, UCLA and the University of Minnesota for comments on earlier versions of this paper. This study was funded by the National Science Foundation. This paper is part of NBER's research program in Labor Studies. Any opinions expressed are those of the authors and not those of the National Bureau of Economic Research. 
NBER Working Paper \#4797

July 1994

\title{
DO UNIONS MAKE \\ ENTERPRISES INSOLVENT?
}

\begin{abstract}
This study investigates the impact of unionization and firm, business line, or establishment
\end{abstract} survival. A consistent empirical finding is that unions raise wages above those found in nonunion firms, and that in a competitive product market one would expect to find that unionized firms would go out of business more than nonunion firms. However, if unions engage in economic rent-sharing, then during periods of economic hardship unionized firms may be able to remain solvent by giving back some of these rents. In order to answer this question we analyze three data sets: a data set on the union status of solvent and insolvent enterprises and business lines from the Compustat files, a data set on the union status of workers who have lost their jobs due to permanent plant closures or business failures obtained by matching files from Current Population Survey, and a data set from the Federal Mediation and Conciliation Service on the outcomes of elections won by unions and on the outcomes of labor-management dispute cases. Overall, our results are consistent with the hypothesis that unions behave in an economically rational manner, pushing wages to the point where union firms may expand less rapidly than nonunion firms, but not to the point where the firm, plant, or business line closes down.

Richard B. Freeman

National Bureau of Economic Research

1050 Massachusetts Avenue

Cambridge, MA 02138

and Harvard University and LSE
Morris M. Kleiner

Humphrey Institute

260 Humphrey Center

University of Minnesota

301 19th Street South

Minneapolis, MN 55455

and NBER 
The worst crime against working people is a company which fails to operate at a profit.

-----Samuel Compers-----

First President, American

Federation of Labor'

Does unionization increase the likelihood that a firm or plant will go out of business?

Or that a firm will drop a line of business that is unprofitable? Does unionization contribute to higher unemployment because unionized plants are more likely to close than nonunion plants?

There are two views on these questions. The "unions kill firms" answer is that unionization increases the rate of insolvency because union wage gains come out of normal profits, pushing firms closer to shutdown points. If this is the case, econometric studies of union effects on profitability will be biased downward because they are limited to the sample of surviving firms. The "rent-sharing view" is that unionization has little effect on firm solvency because union wage gains are a form of rent sharing: higher union wages come out of "excess profits", not normal profits. When union-induced lower profits threaten firm survival, the unions can give concessions, enabling unionized firms to survive as long as nonunion firms (Blanchnower and Oswald 1993).

Which view is correct has implications for workers' choosing whether or not to unionize, and for the conduct of union organizing drives. Although unsupported threats of a shutdown or plant relocation are illegal, such threats or predictions appear to be common in organizing campaigns (Textile Workers v. Darlington Mfg. Co., 1965, and Wall Street Journal, July 28, 1992). A 1988 Gallup Poll found that 35 percent of the population believes that union establishments are "much more likely to go out of business than nonunion establishments" while 51 percent disagree. Among those who disapprove of unions, 45 percent believe unionized 
workplaces are more likely to go out of business, suggesting that this belief may color their attitude toward unionism (Gallup Synopsis of the 1988 Survey of Public Knowledge and Opinion Concerning the Labor Movement).

In this paper we analyze the relation between unionization and firm, business line, or establishment survival using three data sets: a data set on the union status of solvent and insolvent enterprises and business lines from the Compustat I AND II files; a data set on the union status of workers who have lost their jobs due to permanent plant closures or business failures obtained by matching files from Current Population Survey (CPS) January displaced workers with the CPS annual demographic files; and a data set from the Federal Mediation and Conciliation Service on the outcomes of NLRB certification elections won by unions and on the outcomes of FMCS dispute cases.

The first two data sets show that unionization has little discernible effect on firm or business line survival. Because we lack an adequate control group for newly certified units or for existing collective bargaining arrangements whose disputes reach the FMCS, our conclusion from the third data set is simply that the rate of plant closure in new elections or FMCS dispute cases is "relatively" small. Overall, our results are consistent with the hypothesis that unions behave in an economically rational manner, pushing wages to the point where union firms may expand less rapidly than nonunion firms, but not to the point where the firm, plant, or business line closes down.

\section{FIRM SURVIVAL AND UNION BEHAVIOR}

The economic analysis of short run enterprise survival focuses on the factors that determine whether average variable costs (AVC) exceed average revenues (AR) at the profit-maximizing output. As basic economics texts point out, the plant shuts down when 
AVC > AR. Average variable costs depend on labor productivity and compensation, both of which are likely to be influenced by unionism, and on the costs of other variable factors, which are exogenous to unionization. Average revenues will depend on diverse market conditions ${ }^{2}$ that determine entry of competitive firms, and ultimately controls market prices or market shares. Stopping rules developed in analyses of investment and capital budgeting decisions provide more sophisticated versions of the AVC > AR analysis (McCall 1965). These studies also note that the linknge to bankruptcy decisions is complicated by the classes of claimants within publicly traded firms, which include bondholders, bank lenders, and equity holders (Bulow and Shoven 1978).

How might unions affect firms' decision to shutdown a facility? Extant theory holds that unions care about employment of existing members as well as their wages, and the relevant evidence shows that unions give considerable weight to the employment goal. ${ }^{3}$ Unions have Incentives to drive up the wages and benefits of employees at the expense of potential new workers, but should seek to protect the employment of current members as long as those members earn a premium over their next best alternative employment. Thus, as the Gompers quote suggests, the rational union will rarely raise wages in a single or multiperiod framework to the point where the firm is sufficiently unprolitable to go out-of-business (Kuhn 1986). The various concessions that unions granted employers in the 1980s reflects this form of behavior.

There are three possible exceptions to the general expectation that rational unions will not drive firms out of business. First, unions might have limited or incorrect information about normal profits, and thus might drive some unionized firms out-of-business through a faulty assessment of the firms' financial situation. This is most likely in situations in which the firm alleges, validly, that it cannot afford the unions' demands, nor a strike, but refuses to open its books for the union to examine. Under the labor law, a firm that claims that it cannot grant a 
variables for one-digit industry and occupation. The results from adding the various controls reduce the size of the union coefricient to effectively zero. As best as can be told with these data, unionism does not affect the likelihood that a worker will lose his job because of plant closure.

The results in panel B suggest, by contrast, that unionism may marginally increase the probability that a worker is displaced for any reason. Here, the coefficient in column 1 is a significant $\mathbf{0 . 0 8}$, which falls to an insignificant but positive .04 in column 3 . When we examined the reason for the difference between the panel $A$ and panel $B$ results, we found that the biggest difference in displacement between union and nonunion workers turns out to be in seasonal work, which presumably reflects concentration of union workers in construction and construction unions' rational use of unemployment benefits as part of their seasonal work. To assess the importance of construction on displacement, we estimated the effect of unionism on displacement deleting the construction industry. The estimated coeficients in the equation comparable to column 1 was 0.04 and no longer statistically significant. The concentration of unionized workers in construction is the primary reason for the higher displacement for all reasons shown in column 1.

From these calculations we conclude that the relation between unionism and the probability a worker will be displaced for reasons of plant closure (or for any reason) is slightly but not significantly higher in a union setting. Since union establishments tend to be larger than nonunion establishments, moreover, a given closure (other form of group displacement) is likely to produce a larger number of union job-losers than nonunion job-losers. The inference is that the difference in the probability that union and nonunion establishments shutdown is even smaller than the negligible difference in probability that union and nonunion workers are displaced. 


\section{FMCS DATA}

Another source of information on the rate of plant closure in unionized settings comes from the files of the Federal Mediation and Conciliation Service. The FMCS tabulates data on the outcomes of first contract bargaining in workplaces that the NLRB has certified as having voted for unionization, and on outcomes in dispute cases exclusive of certification elections. The data are derived from the Initial Report and Final Report completed by field mediators. The FMCS distinguishes between several potential outcomes in both cases, ranging from agreement between the parties to various administrative actions (referred to other government agencies) to plant/operation closing which the FMCS defines as consisting of "cases where the plant or operation is planning to close in the near future, and no further bargaining is to occur; or the plant or operation has already closed, and no bargaining will occur; or the plant or operation is pending a transfer of ownership, and bargaining has ceased and is not anticipated to resume for an extended period of timen. By inclusion of the transfer category, the FMCS data overstates the extent of closure in these units by our earlier definitions.

Table 6 records the outcome data from the FMCS reports for fiscal year 1986 through fiscal year 1993. Columns 1 and 2 show the outcomes in the cases closed by the FMCS for new NLRB election certifications. Columns 3 and 4 present the outcomes in dispute cases, excluding certification cases, closed by the FMCS. Since the issue in union organizing campaigns is not whether unionization on average reduces firm or establishment survival but whether new unionization causes a plant to close the FMCS data on newly certified NLRB elections is of particular importance. How frequent is it for newly unionized workplaces to close?

The information in column 1 shows that just 341 of nearly 11,000 certification elections, or $3.2 \%$, resulted in a plant closure. Since we lack a control group of "otherwise identical" workplaces that did not choose unionization, we cannot readily determine the effects of unionism 
per se on closure. But the $3.2 \%$ magnitude has some significance in Itself. To take one extreme, assume that none of the newly organized worksites would have closed absent the union drive. Then, we have an upper bound estimate of the risk that newly organized workers face of plant closure: it is $3.2 \%$-. a rather modest upper bound. Alternatively, we can contrast the $3.2 \%$ with estimates of business or, more properly, plant failures. Dun \& Bradstreet figures show business failure rates that vary cyclically, averaging $1.0 \%$ in the period 1985 to 1992 , but somewhat higher in manufacturing, and in some other areas of relatively intense unionization. ${ }^{10}$ Since these figures relate to business failure rather than plant failure they understate the failure rate of facilities. For example, estimates from the Annual Survey of Manufactures show that the annual plant closure rate between 1974 and 1978 was approximately 3.4 percent (Dunne and Roberts 1990)." If we take these measure as crude indicators of the average rate of plant closure absent new unionization, there is virtually no union effect on closure of new plants.

Column 3 of the table shows that 3009 plants were closed out of 168,945 dispute cases before the FMCS -- or 1.8\%. Again, lacking an appropriate control group, we can only approximate the extent to which this closure rate might be attributable to unionization. But, compared to the business or plant failure rates given above, it is hard to argue that there is a notable difference in the rate of closure of plants whose disputes reach the attention of the FMCS and the average establishment. In sum, while the FMCS evidence is limited, the magnitude of closures it reports in unionized settings is consistent with unions having a slight Insignificant effect on plant closure, as in our Compustat and CPS data.

\section{v. CONCLUSION}

Empirical analyses of firm failure and plant closure have not addressed the role of unions in the survival of firms or plants, in part because of a lack of adequate data, and in part 
because the issue lies at the border of labor economics, Industrial relations, and industrial organization. The economic analysis of a unlon as a rational optimizer concerned with members' employment and wages suggests that such an entity will not drive a firm out of business, as long as the firm can pay union members wages above their next best alternative, although it may reduce employment of new workers. Our multivarlate estimates support the view that unions do not drive firms or business lines out of business. In all of our calculations the probability that union firms, or business lines, or union workers suffer plant closures or insolvency is not discernibly different from that of nonunion entitles. While the effect of unions on closure is positive, the effect is too smalt and insignificant to be meaningful. In addition, FMCS data show that even upper bound estimates of the union effect on the viability of newly organized plants are modest. Unions reduce profits but they do not "destroy the goose that lays the golden egg". 
Tahle 1. Mean Characteristics of Existing and Insolvent Firms and Business Lines Three Years Before Insolvency.

\begin{tabular}{|c|c|c|c|c|}
\hline \multirow{2}{*}{$\begin{array}{l}\text { Number of } \\
\text { observations }\end{array}$} & \multicolumn{2}{|c|}{ BUSINESS LINES } & \multicolumn{2}{|c|}{ FIRMS } \\
\hline & 255 & 59 & 252 & 67 \\
\hline Age & 37.50 & 33.12 & 65.0 & 29.4 \\
\hline $\begin{array}{l}\text { Sales } \\
\text { (in millions) }\end{array}$ & 890 & 75.7 & 3,709 & 74.0 \\
\hline $\begin{array}{l}\text { Assets } \\
\text { (in mlllions) }\end{array}$ & 438.6 & 61.4 & 3,113 & 78.9 \\
\hline R\&D / Assets & 0.082 & 0.12 & 0.035 & 0.041 \\
\hline Profits / Assets & 0.11 & -0.05 & $\ldots$ & $\ldots$ \\
\hline $\begin{array}{l}\text { Tobin's Q } \\
\text { (Equity / Assets) }\end{array}$ & $\cdots$ & $\cdots$ & 0.46 & 0.18 \\
\hline Employment & 5,800 & 2,800 & 28,520 & 2,350 \\
\hline $\begin{array}{l}\text { Percent of firms with } \\
\text { any union present }\end{array}$ & 51.0 & 50.8 & 75.6 & 34.3 \\
\hline $\begin{array}{l}\text { Percent of } \\
\text { production workers } \\
\text { unionized }\end{array}$ & 34.0 & 41.1 & 24.0 & 32.6 \\
\hline
\end{tabular}

NOTE: The percentage of firms or business lines with any union present is based on calculations that give a firm with a union in any facility a 1 and a firm with no union in any facility a 0 . 
Tahie 2 Problt Estlmates of Unlon Erfects on Enterprise or BusIness Lae Insolvency (standard errors In parentheses).

\begin{tabular}{|c|c|c|c|}
\hline & \multicolumn{3}{|c|}{ PANEL A } \\
\hline & Column 1* & Column 2 & Colume 3* \\
\hline Unlon Presence & $\begin{array}{c}-.65 \\
(.10)\end{array}$ & $\begin{array}{l}-.20 \\
(.53)\end{array}$ & $\begin{array}{l}.18 \\
(.54)\end{array}$ \\
\hline Age & $\cdots$ & $\begin{array}{c}.001 \\
(.009)\end{array}$ & $\begin{array}{l}. .01 \\
(.09)\end{array}$ \\
\hline Log Sales & - & $\begin{array}{c}-.52 \\
(.18)\end{array}$ & $\begin{array}{l}-58 \\
(.13)\end{array}$ \\
\hline Concesslons & - & - & $\begin{array}{c}.01 \\
(.01)\end{array}$ \\
\hline Log Ukellhood & $-\mathbf{3 0 6 . 4 8}$ & -18.85 & -18.19 \\
\hline \multicolumn{4}{|c|}{ PANEL B } \\
\hline & Column $4^{\circ}$ & Column 5 & Column $\Leftrightarrow$ \\
\hline Low Unlonlzatlon Rate & $\begin{array}{l}-1.06 \\
(.20)\end{array}$ & $\begin{array}{c}.14 \\
(.72)\end{array}$ & $\begin{array}{l}. .08 \\
(.77)\end{array}$ \\
\hline Medlum Unlonlzatlon Rate & $\begin{array}{c}-.95 \\
(.20)\end{array}$ & $\begin{array}{c}-2.98 \\
(64.66)\end{array}$ & $\begin{array}{c}.358 \\
(90.16)\end{array}$ \\
\hline IIIgh Unlonlzation Rate & $\begin{array}{c}.025 \\
(.142)\end{array}$ & $\begin{array}{c}.81 \\
(.63)\end{array}$ & $\begin{array}{c}.97 \\
(.68)\end{array}$ \\
\hline Age & $\cdots$ & $\begin{array}{c}.002 \\
(.010)\end{array}$ & $\begin{array}{l}.001 \\
(.01)\end{array}$ \\
\hline Log Sales & $\cdots$ & $\begin{array}{l}. .52 \\
(.19)\end{array}$ & $\begin{array}{l}-.61 \\
(.22)\end{array}$ \\
\hline Concessions & $\cdots$ & - & $\begin{array}{c}.01 \\
(.11)\end{array}$ \\
\hline Log Ukellhood & -288.77 & .17 .32 & -16.47 \\
\hline
\end{tabular}

\section{$N=633$}

NOTES:

- Whth controls for constant and nrm or line of business.

-. Estlmated with controls Tor constant, Industry dummles, Industry bankruptcy rate, concentration ratios, mlssing values, year, firn or line of business, and Imporl penetratlon. 
Table 3. Union Impacts on Net Income/Assets (standard errors in parentheses).

\begin{tabular}{||l|c|c||}
\hline & $1 *$ & 2 \\
\hline \hline Age & .007 & .007 \\
\hline Log Assets & $(.004)$ & $(.004)$ \\
\hline RD / Assets & .014 & .015 \\
& $(.006)$ & $(.066)$ \\
\hline Union Presence & .003 & .003 \\
& $(.001)$ & $(.001)$ \\
\hline Low Unionization Rate & -.03 & $\ldots$ \\
\hline Medium Unionization Rate & $(.02)$ &. .05 \\
& $\ldots$ & $(.03)$ \\
\hline High Unionization Rate & $\ldots$ & -.05 \\
& & $(.03)$ \\
\hline Constant & $\ldots$ & .05 \\
& & $(.30)$ \\
\hline R &. .08 & .08 \\
\hline N= & $.06)$ & $(.06)$ \\
\hline \hline
\end{tabular}

NOTE:

- With controls for industry growth, industry bankruptcy rate, concentration ratio, import penetration, year, missing values and business line or firm. 
Table 4. Characteristics of Workers, by Displacement and Status.

1983-1990

\begin{tabular}{|c|c|c|c|}
\hline & Not Displaced & $\begin{array}{l}\text { Displaced Because } \\
\text { of } \\
\text { Plant Shutdown }\end{array}$ & All Displaced \\
\hline size site & 185,263 & 497 & 1413 \\
\hline$\%$ union & 15.7 & 17.5 & 19.0 \\
\hline age & 35.6 & 37.4 & 36.5 \\
\hline$\%$ male & 54.6 & 53.1 & 59.8 \\
\hline$\%$ white & 88.0 & 90.5 & 88.7 \\
\hline grade completed & 12.6 & 12.2 & 12.5 \\
\hline $\begin{array}{l}\text { usual weekly } \\
\text { earnings }\end{array}$ & 355 & 327 & 342 \\
\hline$\%$ blue collar & 50.5 & 53.7 & 51.8 \\
\hline$\%$ manufacturing & 27.4 & 29.8 & 30.1 \\
\hline$\%$ retail trade & 22.0 & 30.6 & 23.1 \\
\hline
\end{tabular}

Source:

Tabulated from matched January Displaced Workers for 1984, 1988, and 1990 and Annual Demographic Files of CPS for the preceding years. 
Table 5. Problt Equation Estimates and Standard Errors of the Effect of Unionization on Displacement Because of Plant Closure and For All Reasons (stundard errors are in parenthesis).

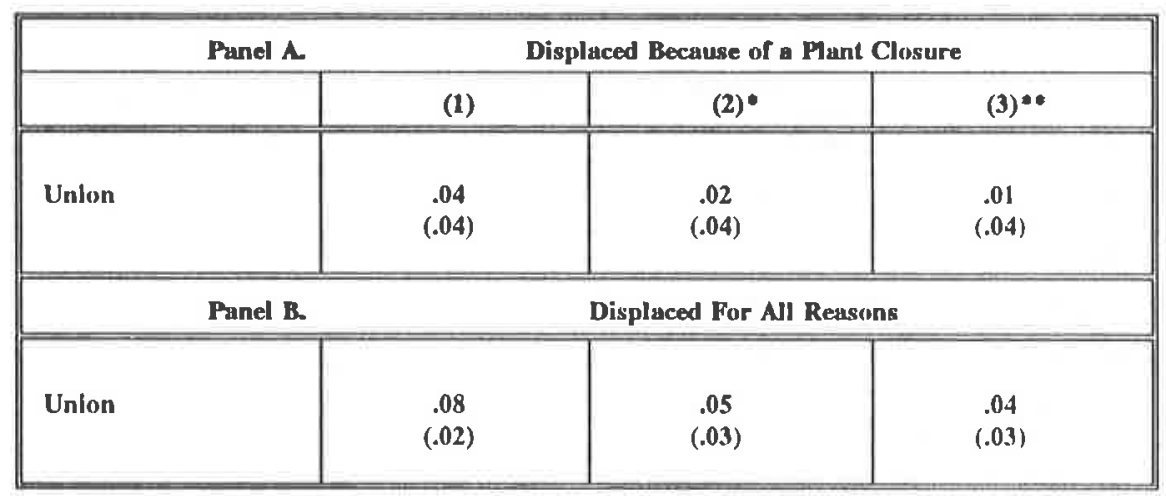

Source: Estimated from matched CPS Displaced Worker/Annual Demographic Files.

- Demographic controts: constant, uge, yeurs of schooling, dummies for sex, race, industry, occupation: dummies for one-digit industry and occupation earnings: usual average earnings

* Demographic controls with industry and occupution. 
Table 6. Outcomes in New NLRB Certified Union Election Victories and in FMCS Dispute Cases, fiscal year 1986 to fiscal year 1993.

\begin{tabular}{|c|c|c|c|c|}
\hline & \multicolumn{2}{|c|}{$\begin{array}{c}\text { NLRB Certified Election } \\
\text { Cases }\end{array}$} & \multicolumn{2}{|c|}{ FMCS Dispute Casea } \\
\hline & \# of Cases & $\begin{array}{l}\text { Percent of } \\
\text { Cases }\end{array}$ & \# of Cases & $\begin{array}{l}\text { Percent of } \\
\text { Cases }\end{array}$ \\
\hline $\begin{array}{l}\text { Number of Certifications } \\
\text { Reason for Closing the Case }\end{array}$ & 10783 & 100.0 & 168,945 & 100.0 \\
\hline Plant Closed & 341 & 3.2 & 3,009 & 1.8 \\
\hline Agreement Reached & 6009 & 55.7 & 136,007 & 80.5 \\
\hline $\begin{array}{l}\text { Diverae Factora for } \\
\text { Closing }\end{array}$ & 488 & 4.5 & 7,520 & 4.5 \\
\hline $\begin{array}{l}\text { Question of } \\
\text { Representation }\end{array}$ & 580 & 5.4 & 1,661 & 1.0 \\
\hline Referred to NLRB & 563 & 5.2 & $\cdots$ & $\ldots$ \\
\hline Other & 2802 & 26.0 & 20,748 & 12.3 \\
\hline
\end{tabular}

- These factors are: state or other mediation; referred to FSIP; referred to FLRA; not in jurisdiction; no need for mediation; administratively closed. Prior to 1991 or 1992 some of these small categories were not distinguished separately. 


\section{ENDNOTES}

1. Great Business Quotations, Rolf B. White, Compiler, Lyle Stuart Inc., Secaucus, N.J., 1986, p. 52.

2. The rate of technological change in the sector, costs of new plant and machinery, interest rates, as well as wages influence the shutdown decision. (See Salter, 1966.)

3. See Freeman and Medoff, 1983; Farber, 1986; and Pencavel, 1984.

4. The Supreme Court in NLRB v. Truitt (1956) ruled that financial information-sharing is required when the employer pleads an inability-to-pay (Kleiner, 1984).

5. See R. Freeman and E. Lazear, "An Economic Analysis of Works Councils" for a model in which full provision of information reduces the likelihood of plant closing but in which the firm profits from nondisclosure.

6. In this vein Blanchflower and Oswald (1989) have argued that British unions serve as a keeper of rents during prosperous times and return profits to the firm during periods of recession. Their analysis shows a lower failure rate of union plants as compared to nonunion plants in the U.K. in the 1980s, consistent with the rent-sharing model.

7. This outcome is subject to various provisos having to do with information, the ease of regaining concessions in succeeding periods, the reputation of the union in bargaining, and the like.

8. An additional test was performed comparing firms that became insolvent with their "closest competitor" and analyzing the paired differences. If pairing correctly gives us a data set of firms that are more alike than other firms the variance of the variable in our sample between pairs should be lower than the variance of randomly selected establishments (Freeman and Kleiner, 1990). We present simple crosstabs on a matched set firms by fourdigit industry and size. Of the nonunion firms $51.9 \%$ survived and $48.1 \%$ of the union firms survived during the period. This point estimate result is not statistically significant. Therefore, our estimates from pairing our firms is consistent with our multivariate estimates.

9. We wanted to analyze the 1986 CPS files as well, but for some arcane reason the codes matching the January displaced worker file to the previous years' CPS were scrambled on the public use data files. The cost of having the Census reconstruct the files to permit matching was too expensive for us.

10. These data are from U.S. Statistical Abstract, various years, to get the Ggures for each year from 1985 to 1992 .

11. The $3.4 \%$ is our calculation of figures from Dunne and Roberts. We divided their $13.5 \%$ rate of plant closure over a four year period from 1974 to 1978 by four. 


\section{REFERENCES}

Becker, Brian E. and Craig A. Olson, "Unions and Firm Profits," Industrial Relations, Vol. 31, No. 3, Fall 1992, pp. 395-432.

Bell, Linda, "Unlon Concessions In the 1980s," Federal Reserve Bank of New York, Quarterly Review, Summer, 1989, pp. 44-58.

Blanchnower, Davld G. and Andrew J. Oswald, "Unionization and Plant Closures," mimeographed, University of Survey and Centre for Labour Economics, London School of Economics, February 1989.

Bronars, Stephen G. and Donald R. Deere, "The Threat of Unionization and the Profitability of the Firm," mimeographed, University of California, Santa Barbara and Texas A\&M, May 1988a.

Bulow, J.I. and J.B. Shoven, "The Bankruptcy Decision," Bell Journal of Economics, Vol. 9, No. 2, Autumn 1978, pp. 437-456.

Clark, Kim B., "Unionization and Firm Performance: The Impact on Prolits, Growth, and Productivity," American Economic Review 74 (December 1984): 893-919.

Connolly, Rohert A., Barry T. Hirsch and Mark Hirschey, "Union Rent Seeking, Intangihle Capital, and Market Value of the Firm," Review of Economics and Statistics 68 (November 1986): 567-77.

Davis, Steve J. and John Haltiwanger, "Gross Job Creation, Gross Joh Destruction and Employment Relocation," Working Paper, 1991.

Domowitz, Ian, R. Glenn Hubbard and Bruce C. Petersen, "The Intertemporal Stability of the Concentration-Margins Relationship," Journal of Industrial Economics 35 (September 1986): 13-34.

Dunne, Timothy and David A. McPherson, "Unionism and Gross Employment Flows," unpublished paper, 1990.

Farber, Henry S., "The Annlysis of Union Behavior," in O. Ashenfelter and R. Layard, Handbook of Labor Economics, Volume 2, Amsterdam/London, pp. 1039-89.

Freeman, Richard B., "Unionism, Price-Cost Margins, and the Return to Capilal," National Bureau of Economic Research Working Paper No. 1164, July 1983. , and Morris M. Kleiner, "The Impact of New Unionization on Wages and Working Conditions," Journal of Labor Economics, January 1990, pp. S-8-S-25. , and Edward Lazear, "An Economic Analysis of Works Councils, Working Paper, 1993. 
, and James L Medoff, What Do Unions Do? New Yorks Basic Books, 1984.

Gallup Poll, 1988.

Great Business Quotations, Rolf B. White, Compiler, Lyle Stuart Inc., Secaucus, NJ., 1986, p. 52.

Hirsch, Barry T., "Innovative Activity, Productivity Growth, and Firm Performance: Are Labor Unions a Spur or a Deterrent?" Advances in Applied Micro-Economics. Vol. 5, Greenwich, CT: JAI Press, 1989.

Labor Unions and Economic Performance of Firms, Upjohn Institute, Kalamazoo, Michigan, 1991.

Hirsch, Barry T. and Robert A. Connolly, "Do Unions Capture Monopoly Profits?" Industrial and Labor Relations Review 41 (October 1987): 118-36.

Karier, Thomas, "Unions and Monopoly Profits," Review of Economics and Statistics 67 (February 1985): 34-42.

Kleiner, Morris, "Public Pollcy Implications of Financial Information Requirements Under the National Labor Relations Act," Journal of Accounting and Public Policy, Vol. 3, No. 4, Winter, 1984, pp. 253-57.

Kuhn, Peter, "Wages, Effort, and Incentive Compatibility in Life-Cycle Employment Contracts," Journal of Labor Economics, Vol, 4, No. 1, (January 1986): 28-49.

Lawrence, Colin and Robert Lawrence, "Manufacturing Wage Dispersion: An End Game Interpretation,: Brookings Papers on Economic Activity, 1985, No. 1, pp. 47-106.

Little, Roderick and Donald Rubin, Statistical Analysis with Missing Data. New York: John Wiley \& Sons, 1987.

McCall, JJ., "The Economics of Information and Optimal Stopping Rules," The Journal of Business, July 1965, pp. 300-317.

NBER Trade Data Files, 1991.

N.L.R.B. v. Truitt Manufacturing $\mathrm{C}_{0 .}$, Supreme Court, 351 U.S. 149, 76S. Ct. 753, 1956.

Pencavel, John, "The Tradeoff Between Wages and Employment in Trade Union Objectives," Quarterly Journal of Economics, 99(2), pp. 215-31.

Ruback, Richard S. and Martin B. Zimmerman, "Unionization and Profitability: Evidence from the Capital Market," Journal of Political Economy 92 (December 1984): 1134-57. 
Sallinger, Michael A., Tobin's q, Unionization, and the Concentration-Profits Relationship,: Rand Journal of Economics 15 (Summer 1984): 159-70.

Salter, W.E.G., Productivity and Technical Change, Cambridge Press, Cambridge U.K., 1966.

Statistical Abstract, various years.

Textile Workers Union v, Darlington Mrg. Co., Supreme Courh, 380 U.S. 263, 1965.

U.S. Census of Manufactures, Bureau of the Census, 1987.

Voos, Paula B. and Lawrence R. Mishel, "The Union Impact on Profits: Evidence from Industry Price-Cost Margin Data," Journal of Labor Economics 4 (January 1986): 105-33.

Wall Street Journal, July 28, 1992, p. A-1. 